\title{
Screening of Mutant Population (M2) for Mungbean Yellow Mosaic Virus Resistance in French Bean
}

\author{
T. C. Archith ${ }^{1 *}$, V. Devappa ${ }^{1}$ and M. Chirag Reddy ${ }^{2}$ \\ ${ }^{1}$ Department of Plant Pathology, of Horticulture, UHS campus, GKVK, \\ Bengaluru - 560 065, India \\ ${ }^{2}$ Department of Post harvest Technology, of Horticulture, UHS campus, \\ GKVK, Bengaluru - 560 065, India \\ *Corresponding author
}

\begin{tabular}{|l|}
\hline K e y w o r d s \\
$\begin{array}{l}\text { Mung bean, } \\
\text { Induced mutation, } \\
\text { Mungbean yellow } \\
\text { mosaic virus, } \\
\text { Scoring, Mutants. }\end{array}$ \\
\hline Article Info \\
\hline $\begin{array}{l}\text { Accepted: } \\
\text { 15 August } 2019 \\
\text { Available Online: } \\
\text { 10 September } 2019\end{array}$ \\
\hline
\end{tabular}

\section{Introduction}

French bean, (Phaseolus vulgaris L.) is a diploid $(2 \mathrm{n}=22)$, with a relatively small genome of $633 \mathrm{Mbp}$ (Arumuganatham and Earle, 1991). In India, it is extensively grown in Himachal Pradesh, Punjab, Haryana,
Karnataka, Andhra Pradesh and Tamil Nadu. Among the diseases, mung bean yellow mosaic virus disease is a major one attacking the crop, which is readily transmitted by whiteflies. Disease symptoms vary from irregular yellow patches of various sizes, which coalesce to form larger patches of 
bright yellow colour and this is accompanied with general stunting of plants. In severe cases, entire leaves may turn yellow, plant bears few flowers and small curved pods (Chenulu et al., 1979). The yield loss due to MYMV in french bean has not been systematically studied. However, the yield loss due to the MYMV in french bean is upto 100 per cent (Marimuthu et al., 1981). The MYMV disease incidence varies from 10 to 100 per cent depending upon the susceptibility of cultivars, crop season and population of whitefly.

Mutation breeding provides the channel for enhancing the genetic variation. Genetic variability may also be created by modulating the effects of mutagens. Adaptation of mutation breeding is promising not only for creating and utilizing the new variability but also as an indispensable approach through which disease resistance might be improved without altering the existing desirable characters. The use of resistant varieties is the most desirable strategy to manage the disease in an economical and environmentallyfriendly way (Sandhu and Singh, 1985). Development of resistance varieties through mutation against the viral diseases continues to be a breeding priority. Hence, screening of elite mutants for identifying resistance to Mung bean yellow mosaic virus with high yielding potential will help to increase the production to a greater extent.

\section{Materials and Methods}

French bean seeds cv. Arka Anoop and Arka Komal was collected from seeds Division, India Institute of Horticulture Research (IIHR), Bengaluru. One thousand seeds of Arka Anoop, were treated with Ethyl Methane Sulphonate (EMS) at the dose of 0.25 per cent. Initially, seeds were soaked in distilled water for $2 \mathrm{~h}$ and then treated with freshly prepared 0.25 per cent EMS solutions in phosphate buffer at $\mathrm{pH} 8.5$ for 4 hours. After 4 hours, treated EMS seeds were washed under running water for an hour to remove the traces of EMS from the seed surface. Treated seeds along with the parent were sown at a spacing of 30 $X 15 \mathrm{~cm}$ to raise the $M_{1}$ generation plants during kharif season.

All $\mathrm{M}_{1}$ plants were harvested individually and planted as plant progeny rows in $\mathbf{M}_{2}$ population along with parent and check variety (Arka Komal) by following the augmented block design during Summer at Department of Plant Pathology block, College of Horticulture, UHS Campus, GKVK, Bengaluru. All the recommended agronomic practices were adopted to raise the crop plants except virus management.

\section{Sowing of $\mathrm{M}_{2}$ population seeds in field}

Sowing of $\mathrm{M}_{2}$ seeds which were collected from the harvested $M_{1}$ population was raised along with parents and standard check varieties in augmented block design at $30 \times 15$ $\mathrm{cm}$ spacing. Sowing was done during summer season 2015. All the recommended agronomic practices were adopted to raise the crop plant as per the package of practices of UHS Bagalkot except virus management. For $\mathrm{M}_{2}$ generation, the 20 seeds from each $\mathrm{M}_{1}$ plant were sown in plant to row method with total number of lines up to 250 and quantitative observations were recorded.

\section{Recording the observation on $\mathbf{M}_{2}$ population plants}

Out of 250 lines sowed, germination was observed only in 214 lines hence data was recorded on germinated lines only. Data was recorded on various quantitative characters of french bean listed in the NBPGR minimal descriptors on five randomly selected competitive plants in each of the families at various phenophases of the crop. 


\section{Scoring for disease incidence}

For assessing the mungbean yellow mosaic virus in french bean genotype, the intensity of the MYMV was calculated according to Banerjee and Kalloo (1987). Observations on disease incidence were recorded in $\mathrm{M}_{2}$ generations at 30, 45 and 60 days after sowing and the cumulative data were obtained to assess the resistance of a given strain. In $\mathrm{M}_{2}$ generation individual plants were observed to assess the disease incidence. Symptom severity grades designated with numerical values of $0-4$ were given on the basis of visual observation to quantify the disease severity. The per cent disease incidence (PDI) was calculated using the formula.

$\mathrm{PDI}=\frac{\text { Number of diseased plants }}{\text { Total number of plants observed }} \times 100$

\section{Results and Discussion}

Mungbean yellow mosaic virus is one of the destructive viral disease affecting the yield potential of french bean both quantitatively and qualitatively. MYMV incidence was first reported in India from the fields of IARI, New Delhi by Nariani (1960). Over-reliance on the usage of chemicals for the control is associated with contamination of ecosystems and also concerned on pathogen resistance build up. Yet managing the disease by means of resistant genotype is an effective, cheapest and safest approach of disease control. Improved resistance to MYMV disease is now the major goal in french bean breeding programs in several bean production countries. In this study, the field screening for MYMV resistance in $\mathrm{M}_{2}$ generation was carried out. In $\mathrm{M}_{1}$ generation, 778 plants had survived out of 1000 seeds of Arka Anoop variety which was treated with $0.25 \%$ EMS and subsequently the seeds from $\mathrm{M}_{1}$ generation plants were harvested individually after attaining full maturity.
At the time of harvest only 300 plants were harvested individually, out of which 250 plants were selected based on disease resistance and visual observation of elite plant characters like plant height, number of pods and good plant type. No significant difference was observed in plants of the $\mathrm{M}_{1}$ population as compared to the parent population.

In $\mathrm{M}_{1}$ population, among 778 plants, 98 plants were showing the symptoms of MYMV and overall disease incidence of the plot was 12.5 per cent (Fig 1). In $\mathrm{M}_{2}$ generation, segregating population was raised by growing 250 plant progenies from $\mathrm{M}_{1}$ generation along with the parent and check varieties. All the viable morphological mutants were scored throughout the growth period. Results of $\mathrm{M}_{2}$ generation showed that line 207 exhibited resistances, while few lines had moderate resistance and rest lines were susceptibility (Fig 2a).

In $250 \quad \mathrm{M}_{2}$ populations, 214 lines had germinated and screened for MYMV incidence; there is no resistant mutant lines evolved against MYMV except one lines (Fig2b).

According to the scoring scale developed by Banerjee and Kalloo (1987) for MYMV the $\mathrm{M}_{2}$ population was categorized into different groups. Out of $214 \mathrm{M}_{2}$ populations screened, a progeny line $\mathrm{M}_{2}$ F28 was observed as resistant, with significant difference as compared to checks (parent and Arka Komal) in growth parameters. Other six progenies $\left(\mathrm{M}_{2} \mathrm{~F} 115, \mathrm{M}_{2} \mathrm{~F} 146, \mathrm{M}_{2} \mathrm{~F} 156, \mathrm{M}_{2} \mathrm{~F} 164, \mathrm{M}_{2} \mathrm{~F}\right.$ 165 and $\mathrm{M}_{2} \mathrm{~F} 217$ ) come under moderate resistance and rest of all are highly susceptible to MYMV (Table 1). At the initial stages of growth some mutant population showed resistant against MYMV but resistance was broken down at final stage. The results are in agreement with the findings of Karthikeyan $e t$ al., (2012) and Chandra Paul et al., (2013). 
Table.1 Grouping of $\mathrm{M}_{2}$ population of french bean screened against MYMV during 2014-15 under irrigated conditions

\begin{tabular}{|c|c|c|c|}
\hline Scale & Description & $\begin{array}{l}\text { Category/ } \\
\text { Reaction }\end{array}$ & $\mathbf{M}_{2}$ population \\
\hline $\mathbf{0}$ & $\begin{array}{l}\text { No plants showing any } \\
\text { symptoms }\end{array}$ & Immune & -Nil- \\
\hline 1 & $\begin{array}{l}1 \% \text { or less plants exhibiting } \\
\text { symptoms }\end{array}$ & Resistant & $-\mathrm{M}_{2}$ F 28- \\
\hline 3 & $\begin{array}{l}1-10 \% \text { plants exhibiting } \\
\text { symptoms }\end{array}$ & $\begin{array}{l}\text { Moderately } \\
\text { resistant }\end{array}$ & $\begin{array}{c}M_{2} F 115, M_{2} F 146, M_{2} F 156, M_{2} F 164, M_{2} \\
F 165, M_{2} \text { F217 }\end{array}$ \\
\hline 5 & $\begin{array}{l}11-20 \% \text { plants exhibiting } \\
\text { symptoms }\end{array}$ & $\begin{array}{l}\text { Moderately } \\
\text { susceptible }\end{array}$ & Nil \\
\hline 7 & $\begin{array}{l}21-50 \% \text { plants exhibiting } \\
\text { symptoms }\end{array}$ & Susceptible & Nil \\
\hline 9 & $\begin{array}{l}51 \% \text { plants exhibiting } \\
\text { symptoms }\end{array}$ & $\begin{array}{c}\text { Highly } \\
\text { susceptible }\end{array}$ & $\begin{array}{l}\text { All population except } \mathrm{M}_{2} \mathrm{~F} 115, \mathrm{M}_{2} \mathrm{~F} 146 \\
\mathrm{M}_{2} \mathrm{~F} 156, \mathrm{M}_{2} \mathrm{~F} 164, \mathrm{M}_{2} \mathrm{~F} 165, \mathrm{M}_{2} \mathrm{~F} 217 \text { and } \\
\mathrm{M}_{2} \mathrm{~F} 28\end{array}$ \\
\hline
\end{tabular}

Fig.1 General view of $\mathrm{M}_{1}$ population of french bean genotypes evaluated under filed condition

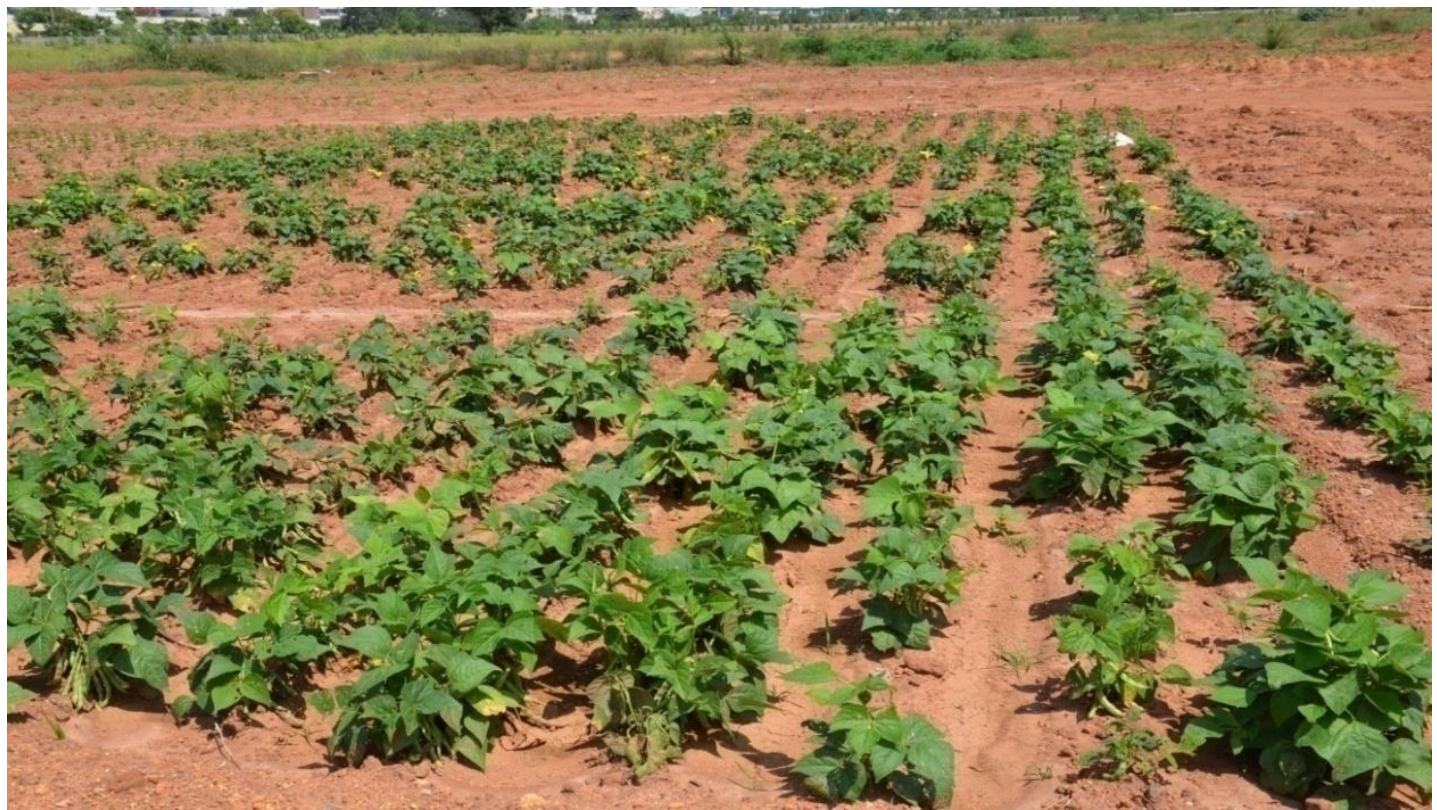


Fig.2 (2a) $\mathbf{M}_{2}$ population showing some moderate resistance (2b) $\mathrm{M}_{2}$ plant showing resistant

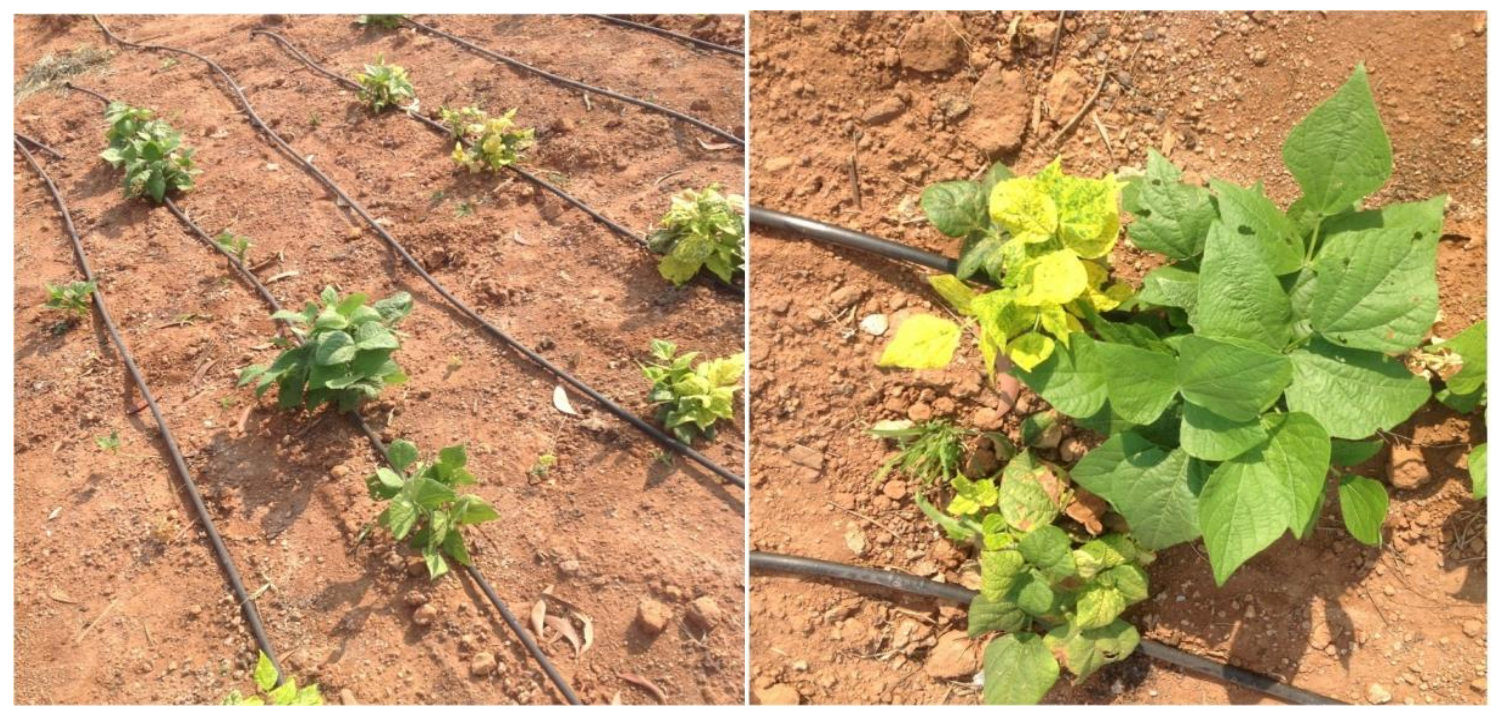

A major constraint in breeding MYMVresistant french bean is field screening for the disease, which is governed by non-uniform development of the disease due to variation of the whitefly population in different locations and different seasons. The summer season was highly favourable for MYMV incidence.

In the present investigation the growth behaviours (plant height, number of days to flowering, and number of seeds per first fruit) of the mutant population exhibited changes in the above-mentioned characters as compared to the checks. This might be due to the biological damage of the embryo as induced by EMS and MYMV disease, this in turn reflected on the plant growth behaviour until maturity (Arisha et al., 2014). Genetically, during the $\mathrm{M}_{1}$ generation the probability of the occurrence of phenotypic mutation is extremely low and only dominant mutations can be identified (Roychowdhury and Tah, 2013). The improvement of the character in a population is limited by variation of that character. Genetic variation of quantitative characters is influenced by environmental effects. The partitioning of the overall variances as genetic and non-genetic components becomes necessary for any breeding programme. Hence, formulation of objectives in breeding programme invariably needs an assessment of existing variability. In $\mathrm{M}_{2}$ generation the range can provide a preliminary idea about the variability. The range being $6.63 \mathrm{~cm}$ to $32.08 \mathrm{~cm}$ for plant height at 30 days after planting; 9.88 to 36.59 $\mathrm{cm}$ for plant height at 45 days after planting; 11.75 to $39.99 \mathrm{~cm}$ for plant height at 60 days after planting; 23 to 71 per cent for germination; 1.86 to 8.93 for number of branches per plant; 3.54 to 10.25 for cluster per plant; 23 to 42 days to 50 per cent flowering; 50 to 62 days to physiological maturity; 17.06 to 38.69 for pods per plant; 9.33 to $16.47 \mathrm{~cm}$ for pod length; 7.06 to 14.26 for seeds per pod; 70.38 to 282.79 for seed yield per plant. Hence, there is considerable scope for selection for these characters as variability is observed in all the characters based on range recorded for each trait. So few promising $\mathrm{M}_{2}$ population with all the desirable characters was identified which could be used in future for crop improvement programmes. In this study, Out of two hundred and fourteen $\mathrm{M}_{2}$ populations screened, one progeny line was observed as resistance, with significant difference as compared to checks (parent and Arka Komal) in growth parameters. Other six 
progenies come under moderately resistant and rest were highly susceptible to MYMV. These resistant and moderately resistant i.e., partial resistant mutants have been subjected for screening different traits like resistance, performance and yield in $\mathrm{M}_{3}$ generation.

\section{References}

Arisha, M. H., Liang, B. K., Shah, S. N. M., Gong, Z. H., and Li, D. W. 2014. Kill curve analysis and response of first generation Capsicum annuum L. B12 cultivar to ethyl methane sulfonate. Genetics and Molecular Research. 13: 10049 - 10061.

Arumuganatham, K and Earle, E. D. 1991. Nuclear DNA content of some important plant species. Molecular Biology Reports. 9: 208-218.

Banerjee, K and Kalloo, G. 1987. Inheritance of tomato leaf curl virus resistance in Lycopersicon hirsutum f.glabratum. Euphytica, 36: 581-584.

Chandra Paul, P., Biswas, Mohan Kumar, Manda, Dipak and Pa, Pinki. 2013. Studies on host resistance of mungbean against mungbean yellow mosaic virus in the agro-ecological condition of Lateritic zone of West Bengal. The Bioscan, 8(2) : 583-587.
Chenulu, V. V., Venkateswarlu, V and Rangaraju, R. 1979. Studies on yellow mosaic disease of mung bean. Indian Phytopathology. 32: 230-235

Karthikeyan, A., Sudha, M., Senthil, N., Pandiyan, M., Raveendran, $\mathrm{M}$ and Nagarajan, P. 2012. Screening and identification of RAPD markers linked to MYMV resistance in mungbean (Vigna radiata (L) Wilczek). Archives of Phytopathology and Plant Protection. 45:712-716.

Marimuthu, T., Subramanian, C. L and Mohan, R. 1981. Assessment of yield losses due to yellow mosaic infection in mung bean. Pulse Crops News Letter. 1: 1-104.

Nariani, T. K. 1960. Yellow mosaic of mung (Phaseolus aureus L.) Indian Phytopathology. 13: 24-29.

Roychowdhury, R and Tah, J. 2013. Mutagenesis-a potential approach for crop improvement, In Crop Improvement: New Approaches and Modern Techniques, ( ${ }^{\mathrm{st}} \mathrm{Edn}$.).

Sandhu, T. S and Singh, K. 1985. Studies on combining ability in mung bean (Vignaradiata (L) Wilczek). Legume Research. 4: 90-94.

\section{How to cite this article:}

Archith, T. C., V. Devappa and Chirag Reddy, M. 2019. Screening of Mutant Population (M2) for Mungbean Yellow Mosaic Virus Resistance in French Bean. Int.J.Curr.Microbiol.App.Sci. 8(09): 1421-1426. doi: https://doi.org/10.20546/ijcmas.2019.809.163 